\title{
FIRST RECORD OF EPINEPHELUS COSTAE (ACTINOPTERYGII: PERCIFORMES: EPINEPHELIDAE) FROM GALICIAN WATERS (NORTH-WESTERN SPAIN): EXPLORING THE NORTHWARD RANGE EXPANSION
}

\author{
Rafael BAÑÓN ${ }^{1 *}$, David VILLEGAS-RÍOS ${ }^{2,3}$, Paula RODRIGUEZ-TAMARGO ${ }^{1}$, Alexandre \\ ALONSO-FERNÁNDEZ ${ }^{1,2}$, David BARROS-GARCÍA ${ }^{4}$, and Alejandro DE CARLOS ${ }^{5}$ \\ ${ }^{1}$ Instituto de Investigaciones Marinas, Consejo Superior de Investigaciones Cientificas, IIM-CSIC, Vigo, Spain \\ ${ }^{2}$ Asociation Ecoloxía Azul - Blue Ecology, Pontevedra, Spain \\ ${ }^{3}$ Cofradia de Pescadores San Martiño, Bueu, Pontevedra, Spain
}

${ }^{4}$ CACTI, Universidade de Vigo, Vigo, Spain

${ }^{5}$ Departamento de Bioquímica, Xenética e Inmunoloxía, Facultade de Bioloxía, Universidade de Vigo, Vigo, Spain

Bañón R., Villegas-Ríos D., Rodriguez-Tamargo P., Alonso-Fernández A., Barros-García D., De Carlos A. 2018. First record of Epinephelus costae (Actinopterygii: Perciformes: Epinephelidae) from Galician waters (north-western Spain): Exploring the northward range expansion. Acta Ichthyol. Piscat. 48 (4): 399-402.

\begin{abstract}
The first record of the goldblotch grouper, Epinephelus costae (Steindachner, 1878), from Galician waters is reported. Two specimens were recorded in the south of Galicia but only one of them was retained. Morphometric and meristic parameters, along with DNA barcoding, confirmed the identification of the preserved specimen whereas the other was identified based on a photograph. Results of the histological examination of the gonads of $E$. costae are also reported, showing a mature female at the beginning of the reproductive cycle. In addition, a review of the northern limit of distribution for the species is carried out.
\end{abstract}

Keywords: NE Atlantic, tropicalisation, morphology, DNA barcoding, fish identification

\section{INTRODUCTION}

Although groupers have traditionally been included in the family Serranidae, they are now included in its own family Epinephelidae (see Smith and Craig 2007, Neubert et al. 2016, Tucker et al. 2016). The genus Epinephelus Bloch, 1793 comprises 90 species worldwide distributed in tropical and subtropical latitudes, including the Mediterranean Sea (Heemstra 1991). Only four Epinephelus species have been recorded in Atlantic European coastal waters (Quéro et al. 2003): Epinephelus costae (Steindachner, 1878), Epinephelus caninus (Valenciennes, 1843), Epinephelus aeneus (Geoffroy Saint-Hilaire, 1817), and Epinephelus marginatus (Lowe, 1834).

Epinephelus costae is a marine demersal fish species inhabiting sandy, muddy, and rocky bottoms, from the shore down to the depth of $300 \mathrm{~m}$, although it is the most abundant in shallow waters. It is native to eastern Atlantic Ocean, from Portugal coasts $\left(\mathrm{ca} .40^{\circ} \mathrm{N}\right)$ to Angola (ca. $13^{\circ} \mathrm{S}$ ), and from the Mediterranean Sea (Craig et al. 2011, Heemstra and Anderson 2016).
The goldblotch grouper is a protogynous hermaphrodite species (Bouain unpublished ${ }^{* *}$, Sembène unpublished ${ }^{* * *}$ ). Unfortunately, only few observations on the reproductive cycle and fecundity of goldblotch grouper from Tunisian waters have been reported in scientific literature (Bouain and Siau 1983).

\section{MATERIAL AND METHODS}

Two specimens of Epinephelus costae were captured close to each other $(\sim 10 \mathrm{~km})$ in the south of the Galician coast during a short period of time (five days). Adot distribution map was created based on georeferenced data reported in online marine biogeographic databases (OBIS and GBIF) including the present records (Fig. 1). The first specimen, weighing 1200 g, was caught on 22 April 2018 by local fishermen using trammel nets, off the Cíes Islands $\left(42^{\circ} 15.007^{\prime}\right.$ $\left.\mathrm{N}, 8^{\circ} 55.449^{\prime} \mathrm{W}\right)$, at $20 \mathrm{~m}$ depth. The individual was sold in the fresh fish market in Cangas (Ria de Vigo), but it was photographed before the sale (Fig. 2). The second specimen

\footnotetext{
" Correspondence: Dr Rafael Bañón, Instituto de Investigaciones Marinas, Consejo Superior de Investigaciones Científicas, IIM-CSIC, c/ Eduardo Cabello 6, 36208 Vigo, Pontevedra, Spain, phone: +34986231930, e-mail: (RB) anoplogaster@yahoo.es, (DV-R) chirleu@gmail.com, (PR-T) paulartamargo@csic.es, (AA-F) alex@iim.csic.es, (DB-G)davbarros@uvigo.es, (ADC)adcarlos@uvigo.es.

** Bouain A. 1984. Moronidés et Serranidés (Poissons Téléostéens) du golfe de Gabès. Ecobiologie et halieutique. PhD thesis, Tunisia University, Tunisia.

${ }^{* * * *}$ Sembène B. 1995. Contribution à la connaissance de l'écobiologie de trois espèces de mérous des côtes sénégalaises (Serranidae, Poissons téléostéens). Mémoire DEA en Biologie et physiologie animales. [MSc Thesis.] Cheikh Anta Diop University, Dakar, Senegal.
} 
(Fig. 2) was caught on 27 April 2018, with a trammel net, off the Onza Island $\left(42^{\circ} 20.3893^{\prime} \mathrm{N}, 8^{\circ} 56.2216^{\prime} \mathrm{W}\right)$, at 15 $\mathrm{m}$ depth. The fish was landed at the Port of Bueu (Ría de Pontevedra) and was retained for a detailed study.

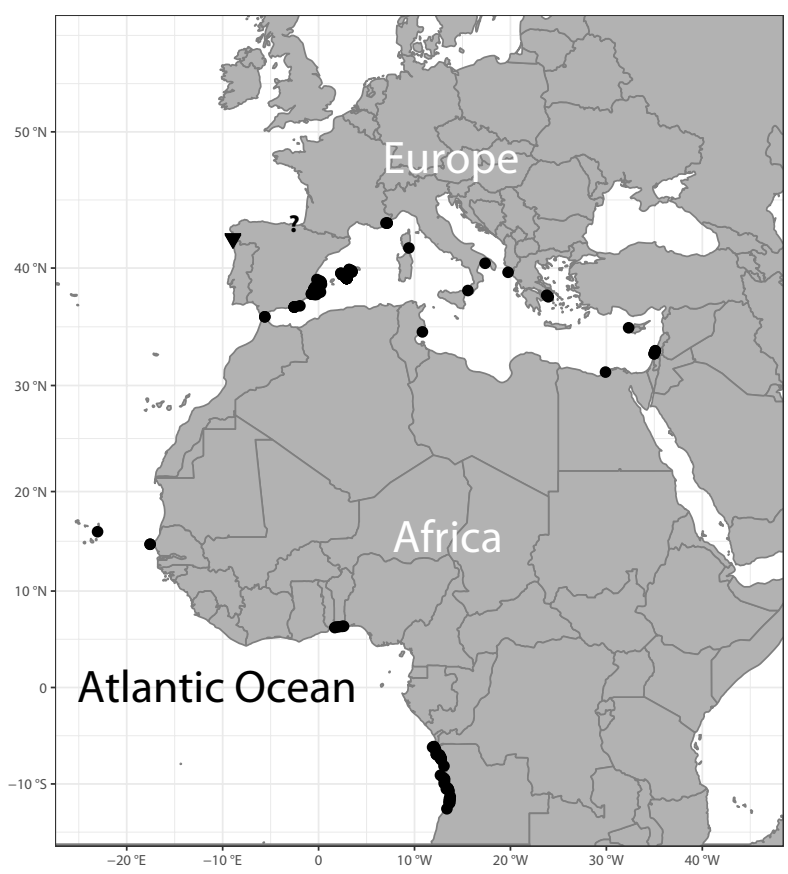

Fig. 1. Distribution map showing georeferenced location points of Epinephelus costae (black circles), the present records in Galician waters (black triangle) and Ibañez (1987) record (question mark)

The main morphometric and meristic characters of the preserved specimen were recorded in fresh following Heemstra (1991). The specimen measured $465 \mathrm{~mm}$ in total length and was preserved in $70 \%$ ethanol and deposited in the fish collection of the "Museo Luis Iglesias de Ciencias Naturais" in Santiago de Compostela with the reference number MHNUSC 25104.

A muscle sample was collected in order to extract DNA and sequence the standard 5' barcoding region of the mitochondrial COI gene, following procedures described elsewhere (Bañón et al. 2016). A 652 nucleotide-long barcode sequence was deposited in the Barcoding of Life Database (process ID FIGAL001-18) and GenBank repositories (accession No. MH308028) and can be found under the project name Marine fishes from Galicia (code FIGAL).

Three serial portions from the gonad were extracted, dehydrated, embedded in paraffin, and sectioned at $3 \mu \mathrm{m}$ and stained with haematoxylin-eosin for histological examination. The specimen was sexed and its maturity phase was determined using histological criteria (BrownPeterson et al. 2011).

\section{RESULTS}

The body of the collected specimen of Epinephelus costae was elongated (Fig. 2); body depth less than head length, contained 3.4 times in standard length; head length contained 2.9 times in standard length; pectoral fins longer than pelvic fins, pectoral-fin length contained 1.8 times in head length; preopercle serrate, with 3 greatly enlarged serrae at the angle; head and body brownish, the fins darker; a large, vaguely defined golden-yellow blotch on body below spinous dorsal fin is apparent in the not preserved specimen. Table 1 shows the main morphometric and meristic characters determined. Meristic and biometric measures are in agreement with previous diagnoses and descriptions of $E$. costae and the molecular identification supports the reliability of the morphological one.

The barcode of the specimen was subjected to query using the BOLD TaxonID Tree tool, resulting in the best identification in favour of E. costae $(99.85 \%)$. GenBank non-redundant nucleotide sequence database was tracked with the same sequence using the BLAST alignment tool, obtaining a $99 \%$ identity with the same species.

The fish examined was a mature female in developing phase (Fig. 3), as revealed by the presence of cortical alveoli oocytes in the ovary (Brown-Peterson et al. 2011). The presence of a cytoplasmic vacuolisation, preceding oocyte vitellogenesis, indicates that the examined specimen was at the beginning of the reproductive cycle (Bouain and Siau 1983).

Table 1

Morphologic characteristics of Epinephelus costae from Galician waters compared to those of the previous report from the Cantabrian Sea (Ibañez 1987)

\begin{tabular}{lrrc}
\hline \multirow{1}{*}{\multicolumn{1}{c}{ Character }} & \multicolumn{2}{c}{ This study } & Ibañez 1987 \\
\cline { 2 - 4 } & {$[\mathrm{mm}]$} & \%SL & {$[\mathrm{mm}]$} \\
\hline MORPHOMETRICS & & & \\
Total length & 465 & & 407 \\
Standard length (SL) & 382 & & - \\
Head length & 132 & 34.6 & 127 \\
Preorbital length & 36 & 9.4 & - \\
Eye diameter & 18 & 4.7 & 16 \\
Postorbital length & 78 & 20.4 & - \\
Interorbital distance & 27 & 7.1 & - \\
Maxillar length & 55 & 14.4 & - \\
Maxillar width & 13 & 3.4 & - \\
Predorsal length & 125 & 32.7 & - \\
Dorsal fin base length & 210 & 55.0 & - \\
Preanal length & 252 & 66.0 & - \\
Anal fin base length & 59 & 15.4 & - \\
Prepectoral length & 123 & 32.2 & - \\
Pectoral length & 74 & 19.4 & - \\
Prepelvic length & 135 & 35.3 & - \\
Pelvic length & 68 & 17.8 & - \\
Caudal depth & 37 & 9.7 & - \\
Body depth & 111 & 29.1 & 105 \\
Body width & 59 & 15.4 & - \\
MERISTICS & & & - \\
No. of dorsal fin rays & XI +15 & & X + \\
No. of anal fin rays & $\mathrm{III}+8$ & & $\mathrm{III}+8$ \\
No. of pectoral fin rays & 18 & & - \\
No. of caudal fin rays & 18 & & - \\
Lateral scale series & 125 & & - \\
Branchiostegal rays & 7 & & - \\
Gill rakers & $9+18$ & & - \\
\hline & & & - \\
\hline & & \\
\hline
\end{tabular}




\section{DISCUSSION}

Although the northernmost Atlantic limit of Epinephelus costae is reported at about $40^{\circ} \mathrm{N}$, the precise data of this limit has not been found in the scientific literature. The presently reported Galician findings should constitute a new northernmost record of distribution for the species. However, a bibliographic revision found a specimen reported as "Epinephelus alexandrinus Valenciennes, 1828", from the Cantabrian Sea, in the Port of Fuenterrabía (Ibáñez 1987). The above-mentioned nominal species is now considered a junior synonym of E. costae. This record has gone unnoticed in the scientific literature, being unreported in the previous revisions of the groupers (Heemstra 1991, Heemstra and Randall 1993, Craig et al. 2011, Heemstra and Anderson 2016). The note of Ibañez (1987) lacks an image of the specimen and has few morphological data (Table 1). However, the reported count of eight soft anal fin rays and a caudal fin truncate give credibility to this identification. In this way, considering the record of Ibáñez as valid, it would be the northernmost one in the Atlantic, expanding the distribution limit northward to $43^{\circ} \mathrm{N}$.

It has been suggested that the recent expansion of some Epinephelus species, such as E. marginatus, E. aeneus, and Epinephelus coioides (Hamilton, 1822) to the Mediterranean Sea and the Atlantic Ocean is the result of the warming of these waters (Parenti and Bressi 2001, Bañón et al. 2017). This warming is evidenced by a rise of $0.24^{\circ} \mathrm{C}$ per decade observed since 1974 in Galician waters as well as by the presence of numerous new southern fish species (Bañón et al. 2014).

Groupers are top predator fishes in food chains and are also among the biggest fishes in coastal marine waters. Therefore, changes in their distribution, abundance, and colonisation abilities would have a significant influence on autochthonous communities (Glamuzina 1999).

\section{ACKNOWLEDGEMENTS}

We would like to thank Berta Rios, the crew of fishing vessel B/ Siempre Pepita, and the staff of Confraria de

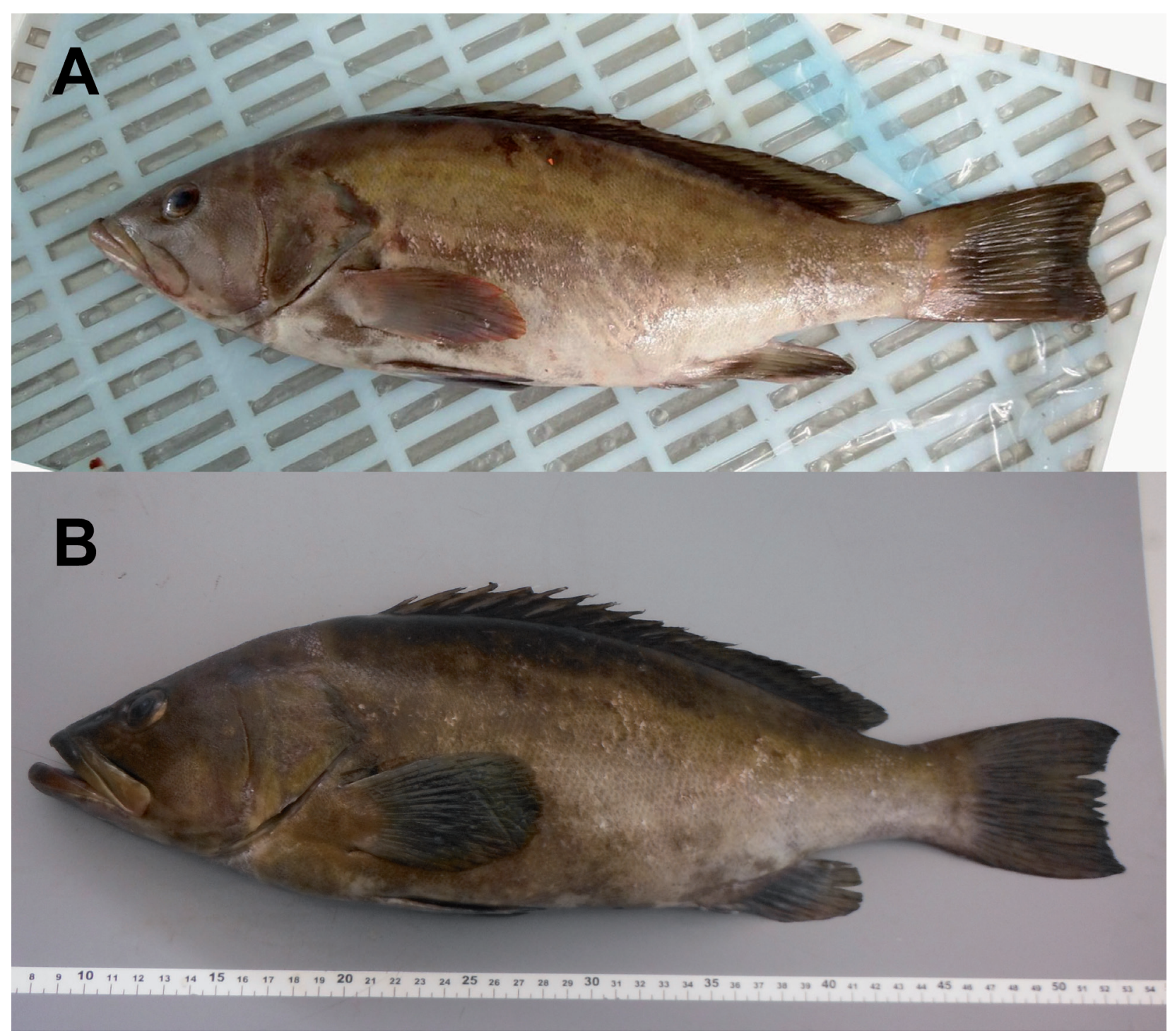

Fig. 2. Epinephelus costae; the specimen (1200 g) caught in the mouth of the Ría de Vigo (A), and the specimen (465 mm TL) caught in the mouth of the Ría de Pontevedra (B) 


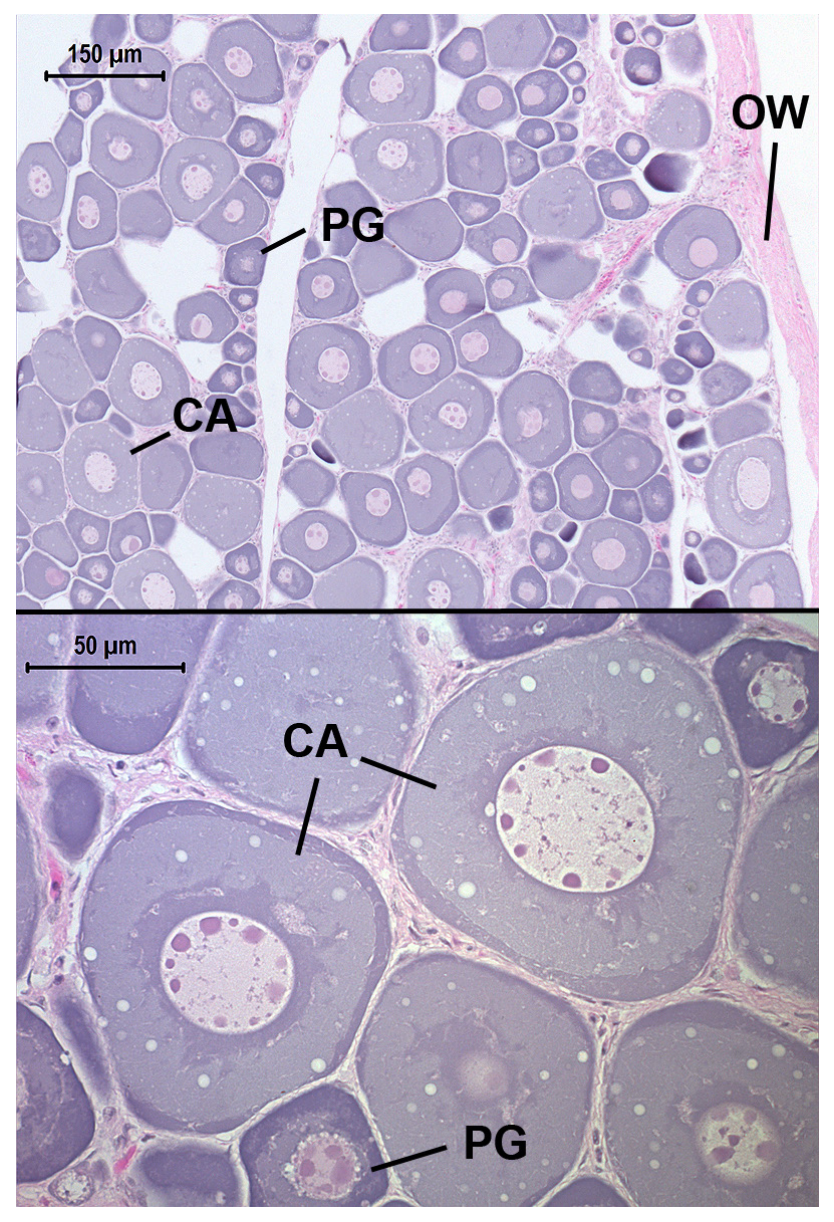

Fig. 3. Histological slide of the ovary of Epinephelus costae caught in Galicia in 2018; $\mathrm{PG}=$ primary growth oocyte; $\mathrm{CA}=$ cortical alveoli oocyte; $\mathrm{OW}=$ ovary wall

Cangas for providing record data. This study was by the agreement between CSIC and Xunta de Galicia to analyse fisheries-dependent data from the monitoring program of small-scale fisheries in Galicia (Agreement No. 070401150009).

\section{REFERENCES}

Bañón R., Alonso-Fernández A., Arronte J.C., BarrosGarcía D., de Carlos A. 2017. New records of two southern fishes found in northern waters of the Iberian Peninsula. Acta Ichthyologica et Piscatoria 47 (4): 401-405. DOI: 10.3750/AIEP/02253

Bañón R., Arronte J.C., Armesto A., Barros-García D., de Carlos A. 2016. Halosaur fishes (Notacanthiformes: Halosauridae) from Atlantic Spanish waters according to integrative taxonomy. Zootaxa 4184 (3): 471-490. DOI: 10.11646/zootaxa.4184.3.3

Bañón R., Barros-García D., Mucientes G., De Carlos A. 2014. Northernmost records of Pagrus auriga (Actinopterygii:Perciformes:Sparidae) and Pomadasys incisus (Actinopterygii: Perciformes: Haemulidae) in the eastern Atlantic. Acta Ichthyologica et Piscatoria 44 (4): 323-327. DOI: 10.3750/AIP2014.44.4.07

Bouain A., Siau Y. 1983. Observations on the female reproductive cycle and fecundity of three species of groupers (Epinephelus) from the southeast Tunisian seashores. Marine Biology 73 (2): 211-220. DOI: 10.1007/BF00406890

Brown-Peterson N.J., Wyanski D.M., Saborido-Rey F., Macewicz B.J., Lowerre-Barbieri S.K. 2011. A standardized terminology for describing reproductive development in fishes. Marine and Coastal Fisheries: Dynamics, Management, and Ecosystem Science 3 (1): 52-70. DOI: 10.1080/19425120.2011.555724

Craig M.T., Sadovy de Mitcheson Y., Heemstra P.C. 2011. Groupers of the world: A field and market guide. CRC Press, Boca Raton FL, USA.

Glamuzina B. 1999. Recent changes of Adriatic ichthyofauna: Threat or benefit to local fishery. CIESM Workshop Series 7: 71-73.

Heemstra P.C. 1991. A taxonomic revision of the eastern Atlantic Groupers (Pisces: Serranidae). Boletim do Museu Municipal do Funchal 43: 5-71.

Heemstra P.C., Anderson W.D. 2016. Serranidae. Pp. 2365 -2413 In: Carpenter K.E., De Angelis N. (eds.). The living marine resources of the Eastern Central Atlantic. Bony fishes part 2 (Perciformes to Tetradontiformes) and Sea turtles, Vol. 4. FAO, Rome.

Heemstra P.C., Randall J.E. 1993. FAO species catalogue Vol. 16. Groupers of the world (family Serranidae, subfamily Epinephelinae): An annotated and illustrated catalogue of the grouper, rockcod, hind, coral grouper, and lyretail species known to date. FAO, Rome.

Ibañez M. 1987. Notas Ictiológicas IX: Presencia de Epinephelus alexandrinus (Valenciennes, 1828) en Fuenterrabía (Guipúzcoa). Lurralde 10: 319-320.

Neubert K., Yulianto I., Kleinertz S., Theisen S., Wiryawan B., Palm H.W. 2016. Parasite fauna of white-streaked grouper, Epinephelus ongus (Bloch, 1790) (Epinephelidae) from Karimunjawa, Indonesia. Parasitology Open 2: e12. DOI: 10.1017/pao.2016.6

Parenti P., Bressi N. 2001. First record of the orangespotted grouper, Epinephelus coioides (Perciformes: Serranidae) in the northern Adriatic Sea. Cybium 25 (3): 281-284.

Quéro J.-C., Porche P., Vayne J.J. 2003. Guide des poissons de l'Atlantique européen. Delachaux and Niestlé, Paris, France.

Smith W.L., Craig M.T. 2007. Casting the percomorph net widely: The importance of broad taxonomic sampling in the search for the placement of serranid and percid fishes. Copeia 2007 (1): 35-55. DOI: 10.1643/0045-8511(2007)7[35:CTPNWT]2.0.CO;2

Tucker S.J., Kurniasih E.M., Craig M.T. 2016. A new species of grouper (Epinephelus; Epinephelidae) from the Indo-Pacific. Copeia 104 (3): 658-662. DOI: 10.1643/CI-16-398

Received: 4 June 2018

Accepted: 13 July 2018

Published electronically: 31 December 2018 